\title{
V O R V
}

Der Titel dieser Blätter spricht ihren Ursprung wie ihre Bestimmung aus. Sie enthalten einen Kranz von Liedern, deren Verfasser sich sämmtlich beim Sächsischen Korps befinden, und diese, während ihrer Trennung vom Vaterlande geschaffenen Produkte, ihren entfernten Landsleuten anspruchslos und mit dem Wunsche übergeben, dafs sie in dieser Gabe das liebevolle $\Lambda$ ndenken an Freunde und Vaterland nicht verkennen mögen. In dieser Rücksicht ist manches Gedicht aufgenommen worden, das der künstlerischen Vollendung zwar noch exmangelnd, doch Gefühle ausspricht, die dem $Z_{w}$ ecke dieser Sammlung so angemessen sind, dafs man es ungern darin vermissen würde, und welches bei 
denen, für die unsre Lieder zunächst bestimmt sind, dennoch eine freundliche Aufnahme hoffen darf; aus diesem Gesichtspunkte möge denn auch die Kritik, falls sie unsre geringe Gabe einer Beachtung werth hält, diese Blätter hetrachten, deren Verfasser in dem freundlichen Gedächtnifs der fernen Landsleute ihre süfseste Belohnung finden würden.

Das Loos des Vaterlandes theilend wird sich bald auch der Kreis trennen, dessen Zusammentritte diese Sammlung ihr Entstehen verdankt, möge man sie denn als ein kleines Denkmal einer Vereinigung kunstliebender Freunde betrachten, die sich unter den Stürmen des Krieges bildete, und die nur zu bald! nicht mehr seyn wird. Aber gewifs wird Jeder unter jeglichem Verhältnisse der Vergangenheit gern gedenken, und von den bekannten Tönen dieser Lieder angesprochen sich der schönen Zeit erinnern, in der sie zum gröfsern Theile entstanden.

Köln im März 1815. 